\title{
FREKUENSI PEMERIKSAAN ANC BERHUBUNGAN DENGAN PREEKLAMPSIA
}

\author{
Lina Fitriani ${ }^{1}$, Rosdiana ${ }^{2}$ \\ ${ }^{1}$ STIKES Bina Generasi Polewali Mandar,Jl Mr Muh Yamin No.195 Manding,Polewali Mandar,Sulawesi \\ Barat,91315, Indonesia \\ E-mail: linafitriani@biges.ac.id

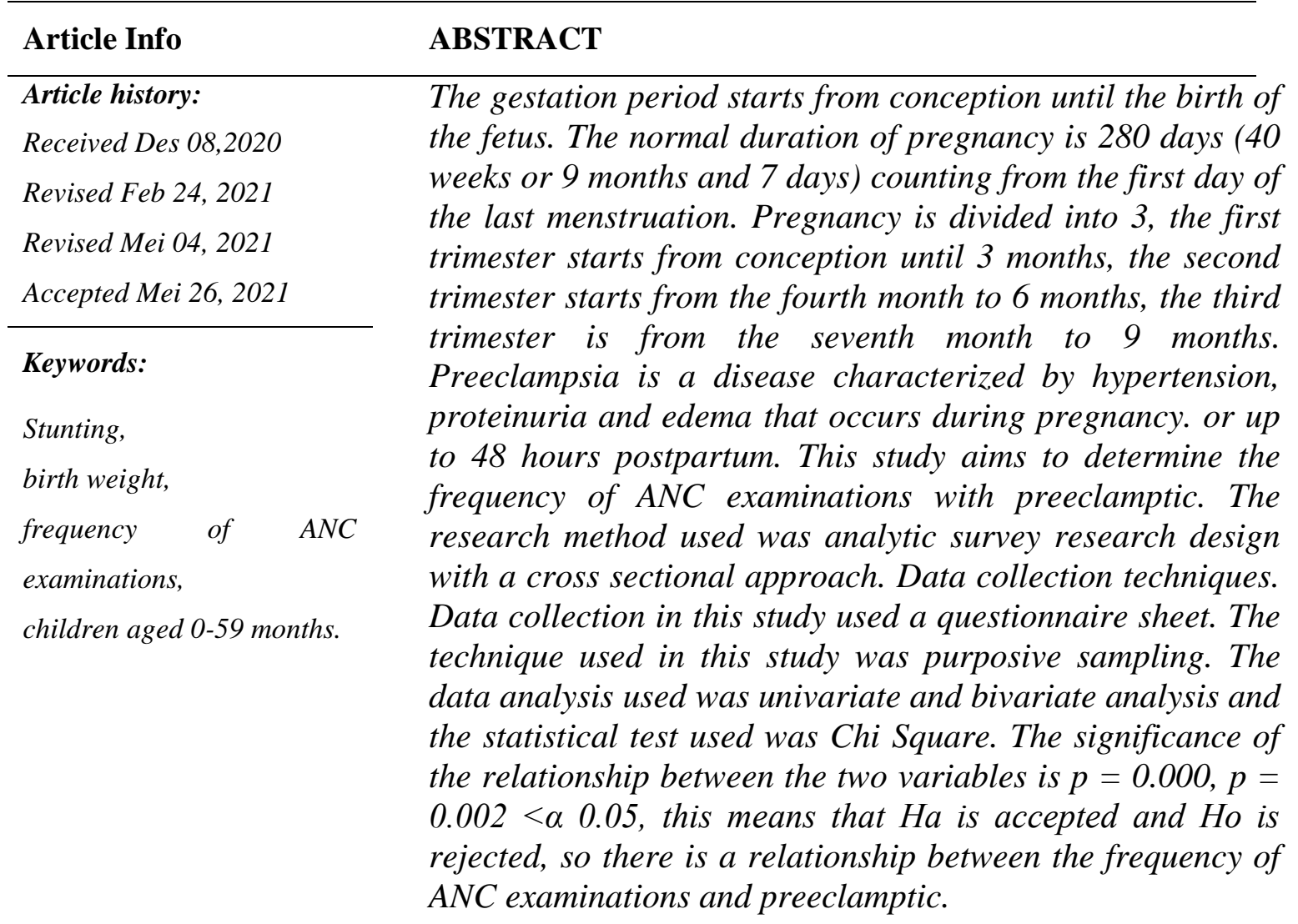

Corresponding Author:

Lina Fitriani ${ }^{1}$ Hilki Ofan ${ }^{2}$,

STIKES Bina Generasi Polewali Mandar, Fakultas Ilmu Keperawatan. Jl Mr Muh Yamin No 195

Manding,Polewali Mandar,Sulawesi Barat,91315, Indonesia

Email,linafitriani@biges.ac.id, rosdinarosdiana3@gmail dan E-mail: linafitriani@biges.ac.id 


\section{PENDAHULUAN}

Kehamilan dan persalinan adalah peristiwa alamiah yang dialami oleh seorang ibu, tetapi bagi ibu yang hamil anak pertama, hal ini sering dianggap sebagai peristiwa yang sangat mencemaskan. Bagi ibu hamil segala sesuatu yang berada disekitar hidupnya akan berpengaruh langsung pada dirinya. Oleh karena itu, banyak ibu hamil akan mengurangi pekerjaannya dengan cara mengurangi pekerjaan yang berhubungan dengan otot.

Menurut Federasi Obstetri Ginekologi Internasional, kehamilan didefenisikan sebagai fertilisasi atau penyatuan dari spermatozoa dan ovum dan dilanjutkan dengan nidasi atau implantasi.

Masa kehamilan dimulai dari konsepsi sampai lahirnya janin. Lamanya hamil normal adalah 280 hari (40 minggu atau 9 bulan 7 hari) dihitung dari hari pertama haid terakhir. Kehamilan dibagi dalam 3, triwulan pertama dimulai dari hasil konsepsi sampai 3 bulan, triwulan kedua dimulai dari bulan keempat sampai 6 bulan, triwulan ketiga dari bulan ketujuh sampai 9 bulan.

Antenatal Care (ANC) yang berkualitas sesuai standar yang telah ditentukan oleh Pemerintah yaitu 2 kali dalam trimester I, 2 kali trimester II dan 4 kali trimester III untuk menurunkan angka kesakitan dan kematian ibu.

Salah satu penyulit dalam kehamilan yang bisa berdampak pada kematian maternal neonatal adalah preeklampsia. Hingga saat ini penyebab pasti dari preeklampsia belum diketahui, diduga usia dan paritas merupakan beberapa factor yang dapat mempengaruhinya. Preeklampsia adalah salah satu penyebab utama kematian ibu dalam bidang obstetri. Faktor predisposisi yangmempengaruhi kejadian preeklampsia diantaranya adalah pelayanan Antenatal Care (ANC)

Preeklamsia adalah sebuah komplikasi pada kehamilan yang ditandai dengan tekanan darah tinggi (hipertensi) dan tanda-tanda kerusakan organ, misalnya kerusakan ginjal yang ditunjukkan oleh tingginya kadar protein pada urine (proteinuria). 
Preeklampsia adalah penyakit yang ditandai dengan adanya hipertensi, proteinuria dan edema yang timbul selama kehamilan atau sampai 48 jam postpartum. Umumnya terjadi pada trimester III kehamilan. Preeklampsia dikenal juga dengan sebutan Pregnancy Incduced Hipertension (PIH) gestosis atau toksemia kehamilan.Penyebab timbulnya preeklampsia pada ibu hamil belum diketahui secara pasti, tetapi pada umum nya disebabkan oleh (vasospasme arteriola). Faktor-faktor lain yang diperkirakan akan mempengaruhi timbulnya preeklampsia antara lain: primigravida, kehamilan ganda, hidramnion, molahidatidosa, multigravida, malnutrisi berat, usia ibu kurang dari 18 tahun atau lebih dari 35 tahun serta anemia.

Preeklampsia dibagi dalam golongan ringan dan berat tanda / gejala: Hipertensi dengan tekanan darah 160/110 $\mathrm{mmHg}$ atau lebih, diukur minimal 2 kali dengan jarak waktu 6 jam pada keadaan istirahat.Proteinuria 5 gram/ 24 jam atau lebih, +++ atau ++++ pada pemeriksaan kualitatif.Oliguria, urine $400 \mathrm{ml} / 24$ jam atau kurang Edema paru-paru, sianosis, Pertumbuhan janin intrauterine terlambat, Adanya HELLP syndrome $(\mathrm{H}=$ Hemolysis, $\mathrm{ELL}=$ Elevated Liver Enzym, $\mathrm{P}=$ Low Plat.Pencegahan timbulnya preeklampsia dapat dilakukan dengan pemeriksaan antenatal care secara teratur. Gejala yang ditangani secara tepat.

Penyuluhan tentang manfaat isirahat akan banyak berguna dalam pencegahan. Istirahat tidak selalu berarti tirah baring di tempat tidur, tetapi ibu masih dapat melakukan kegiatan sehari-hari, hanya dikurangi antara kegiatan tersebut, ibu dianjurkan duduk atau berbaring. Nutrisi penting untuk diperhatikan selama hamil, terutama protein. Diet protein yang adekuat bermanfaat untuk pertumbuhan dan perbaikan sel dan transformasi lipid.

\section{METODE PENELITIAN}

Penelitian ini merupakan penelitian kuantitatif, dengan menggunakan desain penelitian survey analitik dengan pendekatan cross sectional.Tekhnik pengambilan data Pengumpulan data pada penelitian ini menggunakan lembar kuesioner. Teknik yang digunakan pada penelitian ini menggunakan purposive sampling Analisa data yang digunakan adalah analisis univariat dan bivariate dan uji statistic yang digunakan adalah Chi Square. 


\section{HASIL DAN PEMBAHASAN}

Tabel. 1

Hubungan Frekuensi ANC dengan Preeklampsia

\begin{tabular}{ccrrrr}
\hline & & \multicolumn{2}{c}{ Preeklampsia } & Total & p-Value \\
\cline { 3 - 4 } Frekuensi & Teratur & 1 & 8 & 9 & 0,002 \\
Pemeriksa & $\%$ & $2,8 \%$ & $22,8 \%$ & $25,6 \%$ & \\
anANC & Tidak Teratur & 19 & 7 & 26 & \\
& $\%$ & $54,4 \%$ & $20 \%$ & $74,4 \%$ & \\
\hline & Total & 20 & 15 & 35 & \\
& $\%$ & $57,2 \%$ & $42,8 \%$ & $100,0 \%$ & \\
\hline
\end{tabular}

Hasil analisa hubungan kedua variabel diatas dengan menggunakan uji statistik chi-square didapat signifikansi dari hubungan kedua variabel tersebut adalah $\mathrm{p}=$ 0.000, $\mathrm{p}=0,002<\alpha 0,05$ maka ini berarti Ha diterima dan Ho ditolak, maka ada hubungan Frekuensi ANC dengan Preeklampsia Dari hasil penelitian didapatan bahwa dari 35 responden, sebagian besar responden Yang Frekuensi Pemeriksaan ANC Teratur yaitu sebanyak 1 responden $(2,8 \%)$ dan 8 responden yang tidak teratur Frekuensi pemeriksaan ANC (22,8\%), sedangkan Preeaklampsia Ringan sebanyak 19 $(54,4 \%)$ dan preeclampsia berat sebanyak7 responden $(20,0 \%)$.

Untuk menghindari gangguan pada kehamilan, ibu hamil diwajibkan melakukan pemeriksaan Antenatal Care (ANC) yang baik dan teratur. Antenatal Care merupakan suatu pemeriksaan kehamilan yang memiliki beberapa tujuan, yaitu: Memantau kemajuan kehamilan, memastikan kesejahteraan ibu dan tumbuh kembang janin. Meningkatkan dan mempertahankan kesehatan fisik,mental, serta social ibu dan bayi. Menemukan secara dini adanya masalah/gangguan dan kemungkinan komplikasi yang terjadi selama masa kehamilan. Mempersiapkan kehamilan dan persalinan dengan selamat baik ibu maupun bayi dengan trauma seminimal mungkin. 
Mempersiapkan ibu agar masa nifas dan pemberian ASI eksklusif berjalan normal.

Pelayanan ANC berpengaruh pada kejadian preeklampsia dapat terjadi karena masih belum maksimalnya pelayanan ANC yang diberikan kepada ibu hamil. Hal ini sejalan dengan hasil penelitian yang menunjukkan adanya hubungan antara pelayanan ANC dengan kejadian preeclampsia. Sehingga ibu hamil yang tidak rutin memeriksakan kehamilannya mempunyai risiko 9,6 kali untuk mengalami preeclampsia disbanding dengan ibu hamil yang rutin ANC (Isnandaet al., 2014).

Hal ini diperkuat dengan hasil penelitian Nuning dan Mardiana (2016) yang menunjukkan bahwa riwayat preeklampsia berhubungan dengan kejadian preeklampsia (p-value0,0001 dan OR 20,529). Penelitian Grum et al juga menunjukkan bahwa riwayat preeklampsi pada kehamilan sebelumnya berhubungan dengan kejadian preeklampsia (p-value0,001 dan OR 4.28, 95\%CI:1.61-11.43). Menurut Duckitt risiko meningkat hingga 7 kali lipat.

Penelitian ini menunjukkan hasil yang sama dengan penelitian Moghadam et al (2012) yang menunjukkan bahwa riwayat preeklampsia sebelumnya merupakan faktor penting (OR 5,46) yang menimbulkan kekambuhan kembali preeklampsia. Selain itu, penelitian Guerier et al (2013) menunjukkan bahwa riwayat preeklampsia sebelumnya berhubungan kuat dengan kejadian preeklampsia yang memiliki risiko 21 kali untuk terjadi preeklampsia. Hubungan sistem imun dengan preeklampsia menunjukkan bahwa faktor-faktor imunologi memainkan peran penting dalam perkembangan preeklampsia. Keberadaan protein asing, plasenta, atau janin bisa membangkitkan respon imunologis lanjut.

\section{KESIMPULAN}

Berdasarkan hasil uji Chisquare diperoleh hasil bahwa $\mathrm{p}$ value $(0,002)<\alpha(0,05)$ sehingga dapat disimpulkan bahwa Frekuensi Pemeriksaan ANC berhubungan dengan Preeklampsia. 


\section{UCAPAN TERIMA KASIH}

Mengucapkan terimakasih kepada Kepala Puskesmas Pekkabata Kabupaten Polewali Mandar, para Staf dan Kader Puskesmas Pekkabata yang terlibat pada penelitian serta pihak lain yang ikut terlibat dalam penelitian

\section{DAFTAR RUJUKAN}

1. Ayu Gusti,dkk.2016. Asuhan Kebidanan Kehamilan Berbasis Kompetensi. Jakarta:EGC

2. Hani, U. dan Kusbandiyah J. dkk. (2010). Asuhan Kebidanan Pada Kehamilan Fisiologis. Jakarta: Salemba Medika

3. Isnanda, E. P., Noor, M. S., Musafaah, M.(2014). Hubungan Pelayanan Antenatal Care (Anc) Dengan Kejadian Preeklampsia Ibu Hamil Di RSUD Ulin Banjarmasin. Jurnal Publikasi Kesehatan Masyarakat Indonesia

4. Laporan Tahunan Pengurus Cabang Ikatan Bidan Indonesia Kab. Polewali Mandar, "Pengurus Cabang Ikatan Bidan Indonesia Kab.Polewali Mandar,"Ikatan Bidan Indonesia Polewali Mandar, Indonesia,2019

5. Latifin, Khoirul dan Satria Yudha Kusuma. 2014. Panduan Dasar Klinik Keperawatan. Malang: Penerbit Gunung Samudera.

6. Lockhart, Anita dan Lyndon Saputra. 2014. Asuhan Kebidanan Kehamilan Fisiologis \& Patologis. Tangerang Selatan: Binarupa Aksara.

7. Mufdlilah. 2009. Panduan Asuhan Kebidanan Ibu Hamil. Jogjakarta: Nuha Medika.

8. Pratignyo, T. 2014. Yoga Ibu Hamil plus Postnatal Yoga. Jakarta: Pustaka Bunda

9. Prawirohardjo, Sarwono. 2014. Ilmu Kebidanan. Jakarta: PT Bina Pustaka Sarwono Prawirohardjo.

10. Pengurus Cabang Ikatan Bidan Indonesia Kab. Polewali Mandar. 2019. Kabupaten Polewali Mandar.

11. Sofian, Amru. 2011. Rustam Mochtar Sinopsis Obstetri: Obstetri Operatif, Obstetri Sosial. Jakarta: EGC. 
e-ISSN: 2541-4542

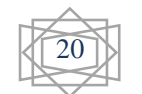

12. Sulistyawati. (2012). Asuhan Kebidanan pada Masa Kehamilan. Jakarta: Salemba Medika

Jurnal Kesehatan Masyarakat, Vol. 07, No. 1, 2021: 14-20 